\title{
COLOR IMAGE ANALYSIS FOR DETERMINING HARVEST TIME OF BEAN AND PEA PODS
}

\author{
A.E. El-Raie ${ }^{1}$, Y.A. Bader ${ }^{2}$, H.E. Hassan ${ }^{3}$, and R. Khamis ${ }^{4}$
}

\begin{abstract}
The main objectives of this research are to study color image analysis for determining the optimal harvest time of green beans (Phaseolus vulgaris L. var Paulista) and green peas (Pisum Sativum L. var Sugar Lays) depending on maturity, and creating the color standards at different ages. Obtained results are summarized as follows: 1) The percentages of color components increased for read $(R)$, green $(G)$ and blue $(B)$ from $29.0 \%$ to $60.4 \%$, from $44.3 \%$ to $76.5 \%$, and from $15.3 \%$ to $49.0 \%$ for pod ages from 10 to 31 days, respectively. Meanwhile, the values for sweet pea pods increased from $26.67 \%$ to $51.76 \%$, from $41.18 \%$ to $61.57 \%$, and from $15.29 \%$ to $29.80 \%$ for pod ages from 6 to 33 days, respectively. 2) The relationships between red color $(R)$, green color $(G)$ and blue color $(B)$ as functions of the pod age $(A)$ resulted as follows:

$R=39.490+3.909 A, G=78.203+3.755 A$, and $B=3.826 A-1.063$ (green bean pods)

$R=52.767+2.423 A, G=96.462+1.817 A$, and $B=34.027+1.080 A$ (sweet peas pods)

3) According to this study, the criteria as a standard for quality depending on the color to determine the optimal harvest time appeared about 22 and18 days for green bean and pea pods (from appearing the pod from its flower) were $34.12 \%(R), 43.04 \%(G)$ and $22.83 \%(B)$ for bean, while they were $33.45 \%(R), 45.99 \%(G)$ and $20.56 \%(B)$ for peas.
\end{abstract}

Keywords: Optimal harvest time, Green beans, Sweet peas, color analysis.

1- Prof. Dr., Agric. Eng. Dep., Fac. of Ageic., Cairo Univ., Egypt.

2\&3- Prof. Dr.,\& Assoc. Prof., Nat. Inst. of Laser Enhanced Sc., Cairo Univ., Egypt.

4- Res., Agric. Eng. Res. Inst, Agric. Res Center, Dokki, Egypt. 


\section{INTRODUCTION}

unasekaran and Paulsen (1986) evaluated several nondestructive testing techniques and concluded that computer vision is the most suitable form of automatic quality evaluations.

Mayer and Davison (1987) used electronic image analysis as a method for non-destructive measurement of in situ leaf area, stem diameter, and leaf and petiole angles of several crops.

Choi et al. (1995) developed a color image analysis procedure to classify fresh tomatoes into six maturity stages according to the USDA standard classification: Green, Breakers, Turning, Pink, Light Red, and Red. RGB (Red, Green, and Blue) images of each tomato were captured and converted to HIS (Hue, Intensity, and Saturation ) values.

Ng. et al. (1998) stated that the extent of color changes in each of the RGB channels was calculated based on an equation derived from the spectral reflectance models. These values formed a transformation matrix that was used to transform the image RGB values to compensate for the color changes.

Hutchings (1999) mentioned that the color scales are often required to describe the changing colors occurring during ripening, processing, or aging. These colors are transitional and change progressively. The color was dominant becomes the background as maturity develops. Colormatching functions were as follows: colors can be specified by weighted sums of red, green, and blue in equation $\quad(\mathrm{C}=r \mathrm{R}+g \mathrm{G}+b \mathrm{~B})$. Where, light-wavelength, visible part (for humans) is from $400 \mathrm{~nm}$ (violet) to $700 \mathrm{~nm}$ (red). The amount $\mathrm{C}$ of each particular stimulus (R), (G) and (B) that is, $r=R /(R+G+B), g=G /(R+G+B)$ and $b=B /(R+G+B)$ Where: $r, g, b$ are the amounts of $R, G, B$ colors, respectively.

Whiteman (1999) mentioned that the additive color process begins with black or the absence of light and therefore no color. It involves transmitted light before it is reflected by a substrate. Adding and mixing the three primary wavelengths of light (red, green, and blue) in different combinations produce a full spectrum of colors. Adding all primary colors in relatively equal amounts produces "white" light. 
The Color Management Company (2000) reported that there are three components necessary for the perception of color: 1) Light, which supplies the spectral energy required for viewing color. We cannot see color in the dark, 2) An object, which modifies the spectral energy from the light source. The different colors affect the light in different ways. For instance, red objects modify the light differently than green objects, and 3) An observer, whose eye and mind perceive color and appearance.

Laykin et al. (2002) developed image-processing algorithms and implemented to provide the following quality parameters for tomato classification: color, color homogeneity, defects, shape, and stem detection. The vision system consisted of two parts: a bottom vision cell with one camera facing upwards, and an upper vision cell with two cameras viewing the fruit. The bottom vision cell determined fruit stem and shape. The upper vision cell determined fruit color, defects, and color homogeneity.

Helmy et al. (2003) concluded that the images processing of digital camera were transmitted to software program by using color analysis, to obtain color component red, green and blue (R, G, and B) and grading of color (hue degree). Fruit mature tomatoes were classified according to color component and grading color into fifteen classes as follows: green, spring, light green, breaker, sand, light orange, peach, turning, faded pink, soft pink, pink, tropical pink, light red, neon red and red. Color component values ( $\mathrm{R}, \mathrm{G}$ and $\mathrm{B}$ ) of class 1 (green color tomato mature) were 142,206 and 9 by the percentage were 39.8, 57.7 and2\%, respectively. The values for class 15 (red color tomato ripeness), were 255,49 and 19 by percentage of $81.1,15.7$ and $3.2 \%$, respectively.

Robert et al. (2004) said that when farmers or ranchers observe their fields or pastures to assess their condition without physically touching them, it is a form of remote sensing; observing the colors of leaves or the overall appearances of plants can determine the plant's condition. Remotely sensed images taken from satellites and aircraft provide a mean to assess field conditions without physically touching them from a point of view high above the field.

The main objectives of the present investigation were to measure color properties and color component analysis of green bean and green pea 
pods at different ages, determining the optimal harvest time of pods according to color components.

\section{MATERIAL AND METHODS}

A vision apparatus was used to make color analysis for the samples. It consists of illumination unit (two lamps with power 400wattes), digital camera and personal computer (Fig. 1): 1) Digital camera: A digital camera was used to take a photo image for different ages of pods. It has the following specifications shown in Table (1); 2) Personal computer connected to the digital camera to transfer image for processing. An image $640 \times 480$ pixels, true color (24 bits), resolution of 118 pixels $/ \mathrm{cm}$ and image bytes of 921600 . This image is transmitted to computer software for image analysis.

Table (1): The specifications of digital camera.

\begin{tabular}{|l|l|}
\hline \multicolumn{1}{|c|}{ Item } & \multicolumn{1}{c|}{ Specification } \\
\hline Model & Sony \\
\hline Model No. & DSC-P200 \\
\hline Image device & $9.11 \mathrm{~mm}(1 / 1.8$ type)color CCD, Primary color filer \\
\hline Total pixel number & Approx. 7 410 000 pixels \\
\hline Lens & $\begin{array}{l}\text { Carl Zeiss Vario-Tessar 3x zoom lens } \\
\text { F=7.9 }-23.7 \mathrm{~mm} \text { (38 - 114mm when converted } \\
\text { to a 35 mm still camera). F2.8 - 5.2 }\end{array}$ \\
\hline Exposure control & $\begin{array}{l}\text { Automatic exposure, Manual exposure, Scene } \\
\text { Selection (9 modes) }\end{array}$ \\
\hline White balance & $\begin{array}{l}\text { Automatic, Daylight, Cloudy, Fluorescent, } \\
\text { Incandescent, Flash, One push }\end{array}$ \\
\hline Recording media & Memory Stick \\
\hline Flash & $\begin{array}{l}\text { Recommended distance (ISO set to Auto): } \\
0.2 \text { to 3.5m (7 7/8 to 11 feet 5 3/4 inches) } \\
\text { (W)/ 0.3 to 2.5m (11 7/8 to 8 feet 2.3/8 inches) (T) }\end{array}$ \\
\hline Screen & LCD \\
\hline Battery pack used & NP-FRI \\
\hline Battery, V & 3.7 \\
\hline
\end{tabular}


Connecting cable

Computer

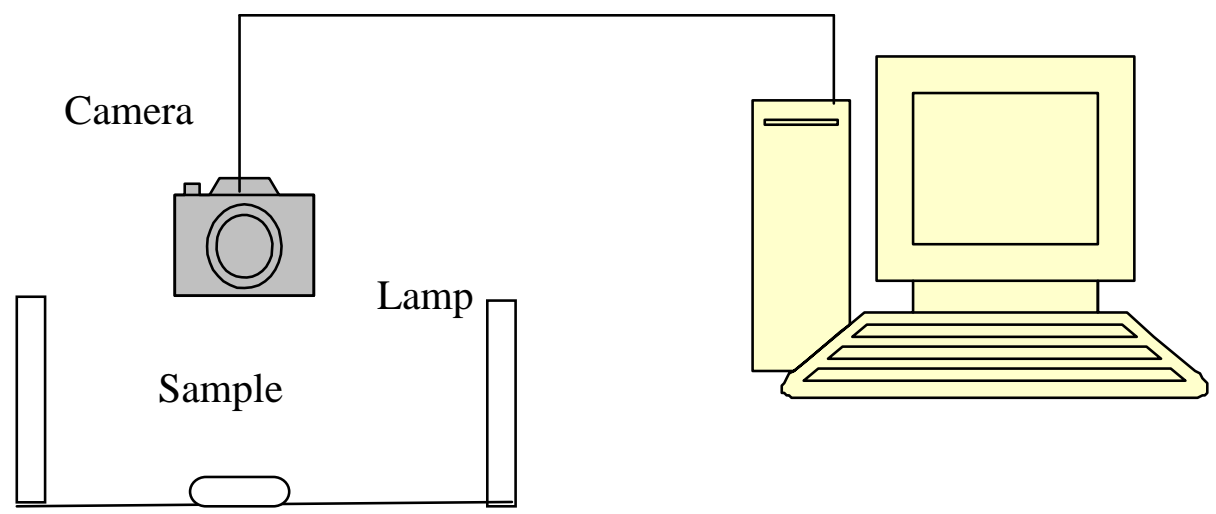

Schematic setup of color analysis.

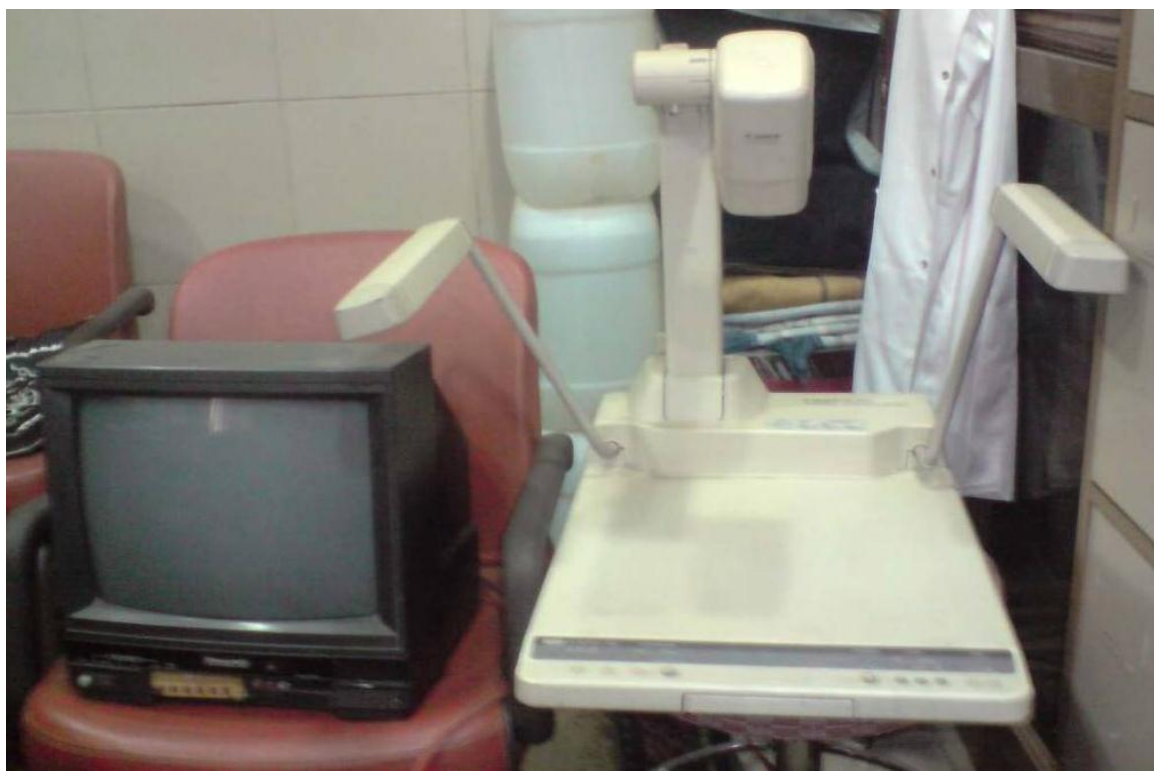

Fig. (1): Vision apparatus for color analysis. 


\section{RESULTES AND DISCUSSION}

The color properties were analyzed by color program using personal computer for the photos of green bean and sweet pea pods at different ages. The data show the distribution components of main colors Red (R), Green (G) and Blue (B) for green bean and sweet pea pods at different ages.

\section{Green bean pods:}

The values and the percentages of color components (R, G, and B) at different ages from the appearance of the pods from the flowers are shown in Table (2). It is noticed that the values of $(G=255)$ component increased from 113 to 195 at pod ages 10 and 31 days, respectively. The green values were higher than the values of red or blue. The values of ( $R$ $=255)$ component increased from 74 to 154 and for $(B=255)$ it increased from 39 to 125 for pod ages from 10 to 31 days, respectively as shown in Fig. (2).

The percentages of color components increased for $(\mathrm{R}),(\mathrm{G})$ and $(\mathrm{B})$ from 29.0 to $60.4 \%$, from 44.3 to $76.5 \%$, and from 15.3 to $49.0 \%$ at pod ages from 10 to 31 days, respectively. The green color was dominant in color component for all ages.

It is clear that the values of color components, red and blue $(R+B)$, increased gradually when the pod's age increased, which affected the appearance of green color. Therefore, when $(\mathrm{R}+\mathrm{B})$ decreased, the appearance of green color increased highly although the percentage of green color component increased when the age increased. Therefore, the earliest ages are darker than the latest ages.

Using the mean values shown in Table (2), the following general equations were deduced to express the relationships between the values of red color (R), green color component (G) and blue color components (B) for green bean pods at different ages from the appearance of the pods.

For the first age (pods at 10 days):

$\mathrm{R}=1.527 \mathrm{G}=0.527 \mathrm{~B}$

For pods at 16 days:

$\mathrm{R}=1.318 \mathrm{G}=0.561 \mathrm{~B}$ 
PROCESS ENGINEERING

Table (2):The values and the percentages of color components for green beans at different ages.

\begin{tabular}{||c||c|c|c|c|c|c|c|c|c||}
\hline \hline \multirow{2}{*}{$\begin{array}{c}\text { Age, } \\
\text { day }\end{array}$} & \multicolumn{3}{||c|}{ Value and percentages of color component } & \multicolumn{4}{c||}{ Color \% } \\
\cline { 2 - 11 } & $\mathrm{R}=255$ & $\%$ & $\mathrm{G}=255$ & $\%$ & $\mathrm{~B}=255$ & $\%$ & $\mathrm{R}$ & $\mathrm{G}$ & $\mathrm{B}$ \\
\hline \hline 10 & 74.0 & 29.0 & 113.0 & 44.3 & 39.0 & 15.3 & 32.74 & 50.00 & 17.26 \\
\hline 13 & 92.0 & 36.1 & 127.0 & 49.8 & 50.0 & 19.6 & 34.20 & 47.21 & 18.59 \\
\hline 16 & 107.0 & 42.0 & 141.0 & 55.3 & 60.0 & 23.5 & 34.74 & 45.78 & 19.48 \\
\hline 19 & 108.0 & 42.4 & 148.0 & 58.0 & 68.0 & 26.7 & 33.33 & 45.68 & 20.99 \\
\hline 22 & 130.0 & 51.0 & 164.0 & 64.3 & 87.0 & 34.1 & 34.12 & 43.04 & 22.83 \\
\hline 25 & 140.0 & 54.9 & 168.0 & 65.9 & 90.0 & 35.3 & 35.18 & 42.21 & 22.61 \\
\hline 28 & 152.0 & 59.6 & 182.0 & 71.4 & 101.0 & 39.6 & 34.94 & 41.84 & 23.22 \\
\hline 31 & 154.0 & 60.4 & 195.0 & 76.5 & 125.0 & 49.0 & 32.49 & 41.14 & 26.37 \\
\hline
\end{tabular}

For pods at 22 days:

$\mathrm{R}=1.262 \mathrm{G}=0.669 \mathrm{~B}$

For the last age (pods at 31 days):

$\mathrm{R}=1.266 \mathrm{G}=0.812 \mathrm{~B}$

Generally, the following equations summarize the relationships between $\mathrm{R}, \mathrm{G}$ and $\mathrm{B}$ as a function of the pods age (A).

$\mathrm{R}=39.490+3.909 \mathrm{~A}, \quad \mathrm{r}^{2}=0.219$

$\mathrm{G}=78.203+3.755 \mathrm{~A}, \mathrm{r}^{2}=0.954$

$\mathrm{B}=3.826 \mathrm{~A}-1.063 ; \mathrm{r}^{2}=0.865$

The equations ( 6 through 8 ) indicate that the age affects green color by percentage higher than the other colors (red and blue).

Fig. (3) illustrates the color percentage of main color components (R, G, and B) at different ages of green bean pods. The percentages of color 


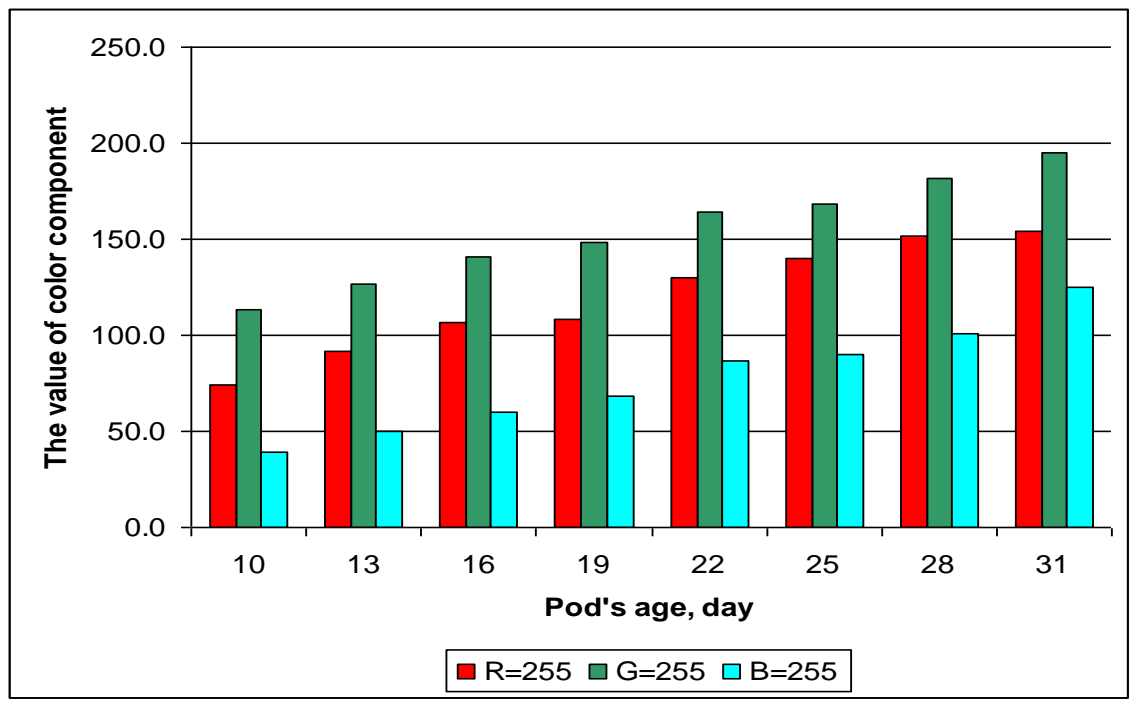

Fig. (2): The values of color components $(\mathrm{RGB}=255)$ for green bean pods at different ages.

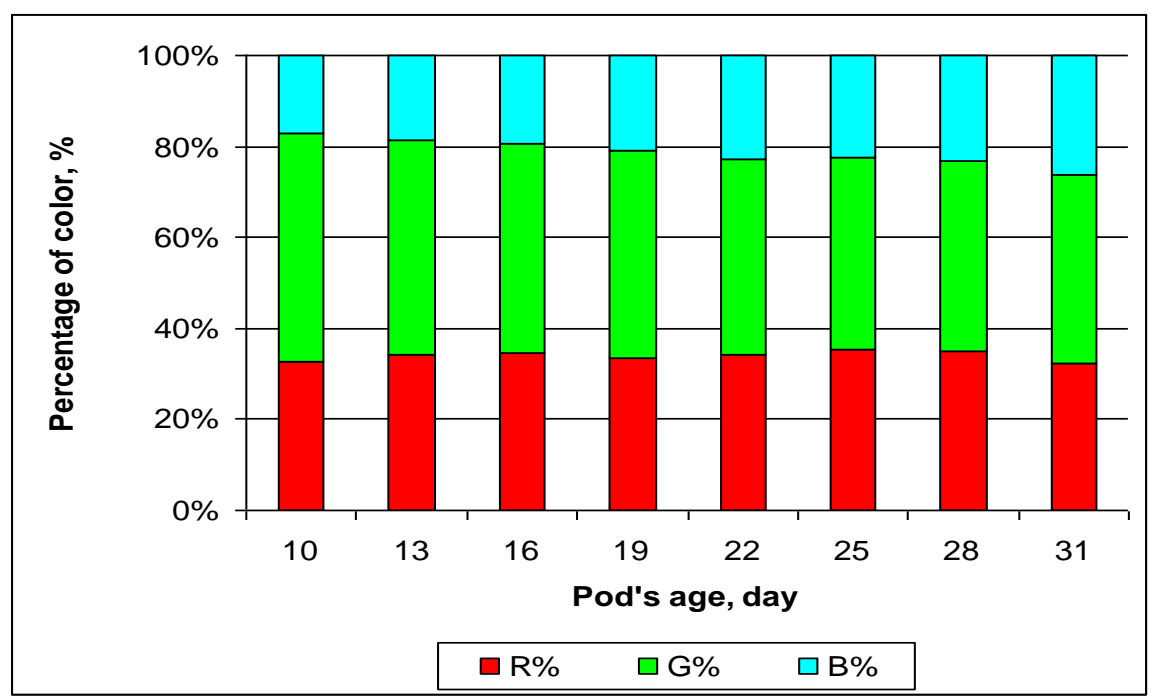

Fig. (3): The percentage of color components (RGB\%) for green bean pods at different ages from the appearance of the pods from flowers. 
components based on maximum value of red, green, and blue colors, were 255 for each. For the green color, the component percentage decreased from $50.00 \%$ to $41.14 \%$ when the pod's age increased from 10 to 31 days, respectively. Meanwhile, the other percentages of red or blue colors do not behave any trend to increase or decrease. The (R) and (B) percentages lie between 32.49 and $35.18 \%$ and between 17.26 and $26.37 \%$, respectively.

\section{Sweet pea pods:}

The values and the percentages of color components (R, G, and B) at different ages are shown in Table (3). It is noticed that the values of green color $(\mathrm{G}=255)$ component increased from 105 to 157 for pods ages 6 to 33 days, respectively.

The green values were higher than the values of red or blue. The values of $(\mathrm{R}=255)$ component increased from 68 to 132 and for $(\mathrm{B}=255)$ values increased from 39 to 76 for pod ages from 6 to 33 days, respectively as shown in Fig. (4).

The percentages of color components increased for $(R),(G)$ and (B) from 26.67 to $51.76 \%$, from 41.18 to $61.57 \%$, and from 15.29 to $29.80 \%$ for pod ages from 6 to 33 days, respectively. The green color was sovereign in color component for all ages.

It is clear that the values of color components, red and blue $(R+B)$, increased gradually when the pod's age increased, which affected the appearance of green color. Therefore, when $(\mathrm{R}+\mathrm{B})$ decreased, the appearance of green color increased highly, although the percentage of green color component increased when the age increased. Therefore, the early ages are darker than the latest ages.

The green values were higher than the values of red or blue. The values of $(\mathrm{R}=255)$ component increased from 68 to 132 and for $(\mathrm{B}=255)$ they increased from 39 to 76 for pods ages from 6 to 33 days, respectively as shown in Fig. (4).

The percentages of color component increased for $(\mathrm{R}),(\mathrm{G})$ and $(\mathrm{B})$ from 26.67 to $51.76 \%$, from 41.18 to $61.57 \%$, and from 15.29 to $29.80 \%$ for pod ages from 6 to 33 days, respectively. The green color was sovereign in color component for all ages. It is clear that the values of color components, red and blue $(\mathrm{R}+\mathrm{B})$, increased gradually when the pod's age 
increased, which affected the appearance of green color. Therefore, when $(\mathrm{R}+\mathrm{B})$ decreased, the appearance of green color increased highly, although the percentage of green color component increased when the age increased. Therefore, the early ages are darker than the latest ages. Using the mean values shown in Table (3), the following general equations were deduced to express the relationships between the value of red color component $(\mathrm{R})$, the value of green color component $(\mathrm{G})$ and the value of blue color component (B) for green pea pods at different ages from the appearance of the pods.

For the first age (pods at 6 days):

$\mathrm{R}=1.544 \mathrm{G}=0.574 \mathrm{~B}$

Table (3):The values and the percentages of color components for sweet peas at different ages.

\begin{tabular}{||c||c|c|c|c|c|c|c|c|c||}
\hline \hline \multirow{2}{*}{$\begin{array}{c}\text { Age, } \\
\text { day }\end{array}$} & \multicolumn{5}{|c|}{ Value and percentages of color component } & \multicolumn{4}{c||}{ Color \% } \\
\cline { 2 - 11 } & $\mathrm{R}=255$ & $\%$ & $\mathrm{G}=255$ & $\%$ & $\mathrm{~B}=255$ & $\%$ & $\mathrm{R}$ & $\mathrm{G}$ & $\mathrm{B}$ \\
\hline \hline 6 & 68.0 & 26.67 & 105.0 & 41.18 & 39.0 & 15.29 & 32.08 & 49.53 & 18.40 \\
\hline 9 & 75.0 & 29.41 & 113.0 & 44.31 & 45.0 & 17.65 & 32.19 & 48.50 & 19.31 \\
\hline 12 & 82.0 & 32.16 & 121.0 & 47.45 & 47.0 & 18.43 & 32.80 & 48.40 & 18.80 \\
\hline 15 & 87.0 & 34.12 & 124.0 & 48.63 & 55.0 & 21.57 & 32.71 & 46.62 & 20.68 \\
\hline 18 & 96.0 & 37.65 & 132.0 & 51.76 & 59.0 & 23.14 & 33.45 & 45.99 & 20.56 \\
\hline 21 & 105.0 & 41.18 & 135.0 & 52.94 & 54.0 & 21.18 & 35.71 & 45.92 & 18.37 \\
\hline 24 & 112.0 & 43.92 & 137.0 & 53.73 & 50.0 & 19.61 & 37.46 & 45.82 & 16.72 \\
\hline 27 & 113.0 & 44.31 & 140.0 & 54.90 & 56.0 & 21.96 & 36.57 & 45.31 & 18.12 \\
\hline 30 & 130.0 & 50.98 & 155.0 & 60.78 & 70.0 & 27.45 & 36.62 & 43.66 & 19.72 \\
\hline 33 & 132.0 & 51.76 & 157.0 & 61.57 & 76.0 & 29.80 & 36.16 & 43.01 & 20.82 \\
\hline
\end{tabular}


For pods at 12 days:

$\mathrm{R}=1.476 \mathrm{G}=0.573 \mathrm{~B}$

For pods at 18 days:

$\mathrm{R}=1.375 \mathrm{G}=0.615 \mathrm{~B}$

For the last age (pods at 33 days):

$\mathrm{R}=1.189 \mathrm{G}=0.576 \mathrm{~B}$

Generally, the following equations summarize the relationships between $\mathrm{R}, \mathrm{G}$ and $\mathrm{B}$ as functions of the pod's age (A).

$\mathrm{R}=52.767+2.423 \mathrm{~A}, \mathrm{r}^{2}=0.934$

$\mathrm{G}=96.462+1.817 \mathrm{~A}, \mathrm{r}^{2}=0.920$

$\mathrm{B}=34.027+1.080 \mathrm{~A}, \mathrm{r}^{2}=0.518$

The equations (from 13 to 15) indicate that: the age affects green color and red color by percentages higher than the blue color.

Fig. (5) illustrate the color percentage of main color components (R, G, and B) at different ages of sweet pea's pods. The percentage of color components is based on maximum value of red, green, and blue colors, which were 255 for each. For the green color, the component percentage decreased from $49.53 \%$ to $43.01 \%$ when the pod's age increased from 6 to 33 days, respectively. On the other hand, the other percentages of red or blue colors do not have any trend to increase or decrease. The (R) percentage lies between 32.08 and $37.46 \%$ and (B) percentage lies between 16.72 and $20.82 \%$.

\section{CONCLUSION}

From the obtained results, the following conclusions can be made:

1) The percentages of color components increased for read (R), green $(\mathrm{G})$ and blue (B) from $29.0 \%$ to $60.4 \%$, from $44.3 \%$ to $76.5 \%$, and from $15.3 \%$ to $49.0 \%$ for pod ages from 10 to 31 days, respectively.

2) Meanwhile, the values for sweet pea pods increased from $26.67 \%$ to $51.76 \%$, from $41.18 \%$ to $61.57 \%$, and from $15.29 \%$ to $29.80 \%$ for pod ages from 6 to 33 days, respectively.

3) The following equations summarize the relationships between red color $(\mathrm{R})$, green color $(\mathrm{G})$ and blue color $(\mathrm{B})$ as functions of the pods age (A):

$\mathrm{R}=39.490+3.909 \mathrm{~A}, \mathrm{G}=78.203+3.755 \mathrm{~A}$, and $\mathrm{B}=3.826 \mathrm{~A}-1.063$ (green bean). 


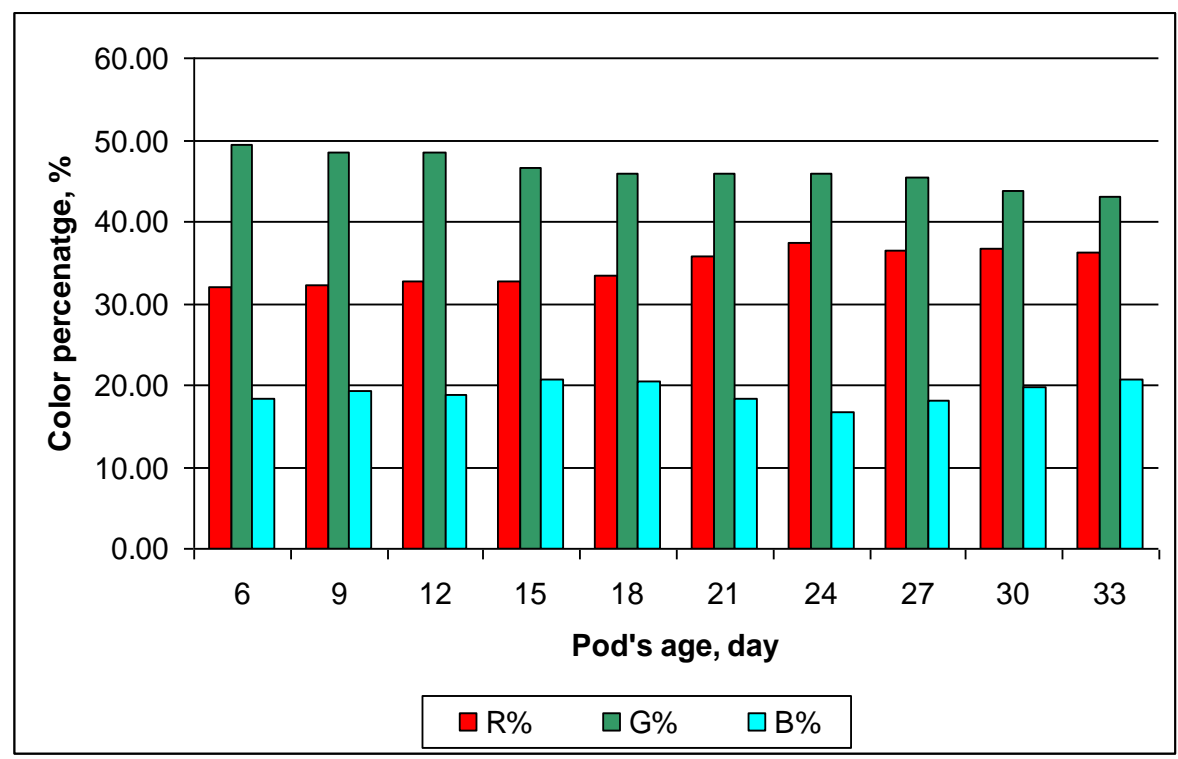

Fig.(4): The values of color components $(\mathrm{RGB}=255)$ for sweet peas pods at different ages.

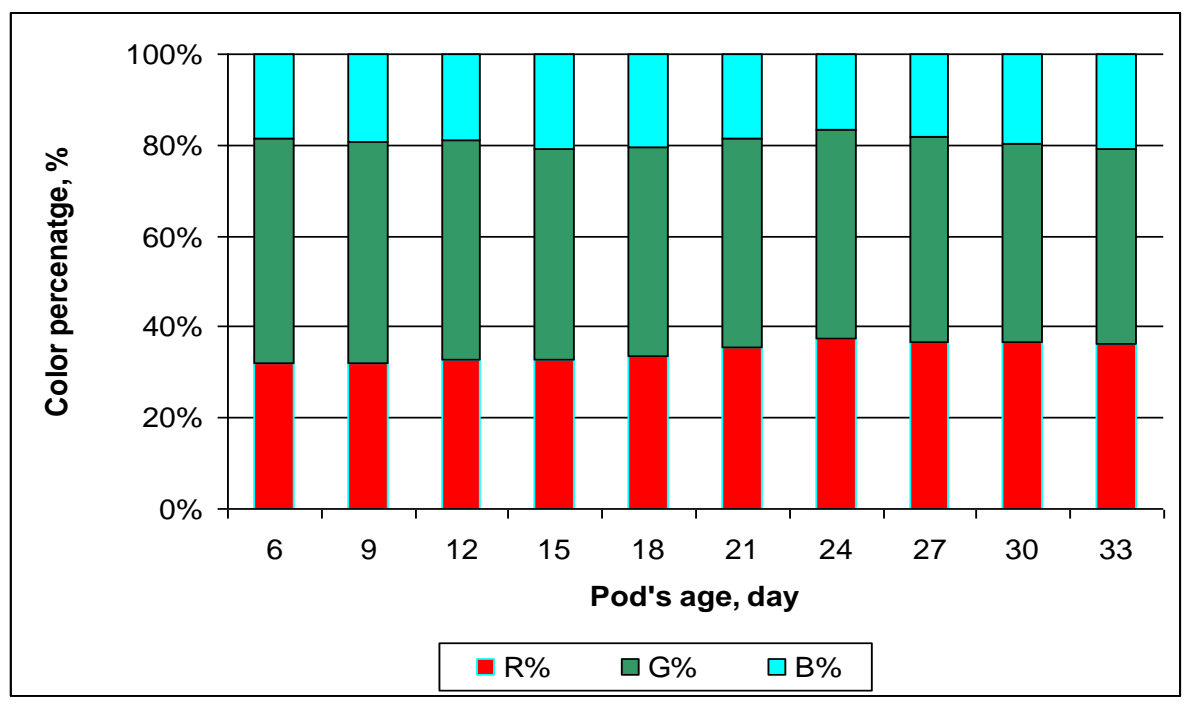

Fig. (5): The percentage of color components (RGB) for sweet pea pods at different ages from the appearance of the pods from flowers. 
$\mathrm{R}=52.767+2.423 \mathrm{~A}, \mathrm{G}=96.462+1.817 \mathrm{~A}$, and $\mathrm{B}=34.027+1.080 \mathrm{~A}$ (sweet peas).

4) The optimal harvest time is about 22 and18 days for green bean and peas pod (from appearance the pod from flower) which has $34.12 \%(R)$, $43.04 \%(\mathrm{G})$ and $22.83 \%(\mathrm{~B})$. For bean, meanwhile, color components were $33.45 \%(\mathrm{R}), \mathbf{4 5 . 9 9 \%}(\mathrm{G})$ and $20.56 \%(\mathrm{~B})$ respectively.

\section{REFERENCES}

Choi, K.; G. Lee; Y. J. Han and J. M. Bunn. 1995. Tomato maturity evaluation using color image analysis. Trans. ASAE. 38(1): 171176.

Helmy M. A., A. A. AbdEl-Rahman and H. E. Hassan 2003. Classification of tomato fruits using color image analysis technique. Misr J. of Agric. Eng., 20(3): 597 - 608.

Hutchings, J. B. 1999. Food color and appearance, a Chapman and Hill, Food Sc. B., Inst. Physics, UK, Gaithersburg, Maryland 2 nd., Aspen Publ. Inc. : 171-172.

Laykin, S.; V. Alchanatis; E. Fallik and Y. Edan. 2002. Image processing algorithms for tomato classification. Trans. ASAE. 45(3): 851-858.

Mayer, G. E. and D. A. Davison. 1987. An electronic image plant growth measurement system. Trans. ASAE 30(1): 242-248.

Ng, H. F.; W. F. Wilcke; R. V. Morey and J. P. Lang. 1998. Machine vision color calibration in assessing corn kernel damage. Trans. of the ASAE. Vol. 41(3): 727-732.

Ounasekaran, P. and O. Paulsen. 1986. Performance evaluation of the four classes of textural features. Pattern recognition 25: 829-833.

Robert, A.; N. John and K. Karry. 2004. Agricultural, Remote Sensing basics, NDSU Ext. Servi., and North Dakota State Univ., Fargo, North Dakota 58105: 1-4.

The Color Management Company. 2000. Components of the color perception. The visual observing situation. Tech. Servi. Dep., Hunter Assoc. Lab., Inc. Virginia, USA, 12 (5): 1-8.

Whiteman, T. A. 1999. Additive color process (RGB). The magazine of the Graphic Arts Technical Foundation, No. 53, $2^{\text {nd }}$ S.: 1-4. 
PROCESS ENGINEERING

\section{الملخص العربيى}

\section{التحليل اللوني لتحديد وقت الحصاد لقرون القاصوليا والبسلة}

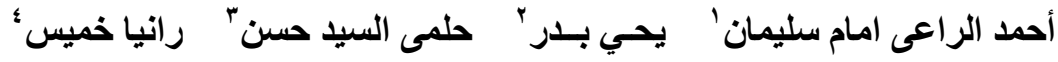

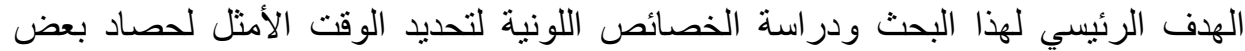
الخضروات اعتمادا على درجة النضج لبعض الخضروات ، مثل الفاصوليا (صنف بوليستا)

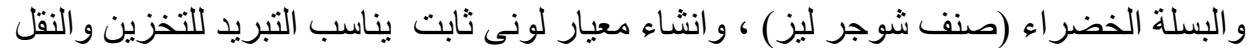
خلال دورة التسوق و التصدير. أجريت التجارب فى معمل تطبيقات الليزر فى الهندسة الزر اعية ، بالمعهد القومى لعلوم الليزر -

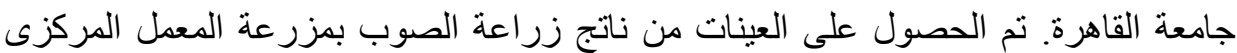

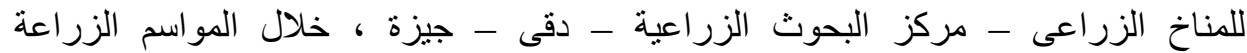

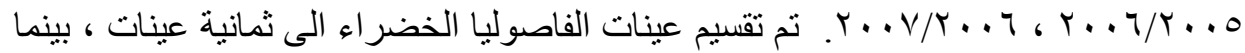
قسمت عينات البسلة الخضر اء الى عثر عينات ، منذ خروج القرن من الزهرة وحتى مرحلة الجفاف و الاصفر ار. ويمكن ايجاز النتائج التى تم الحصول التهول عليها فى الاتى: ا - تزداد قيم مكون الألوان الأخضر والأحمر والأزرق لقدئ لقرون الفاصوليا والبسلة

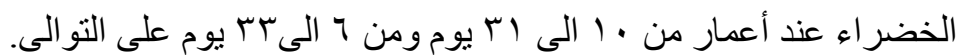

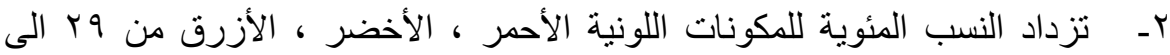

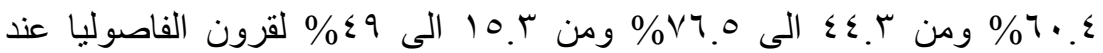

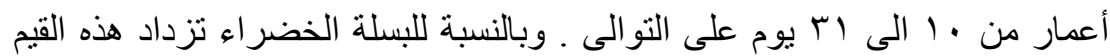

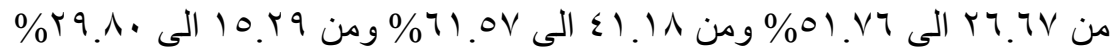

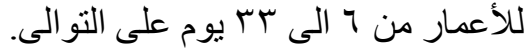

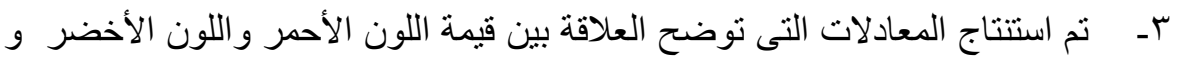
اللون الأزرق كدالة فى عمر القرون.

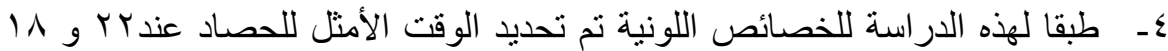
يوم تقريبا لقرون الفاصوليا والبسلة الخضراء منذ ظهور ها من الزهرة هرة (على

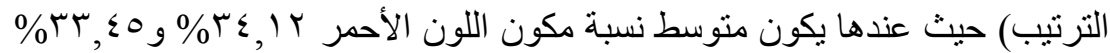

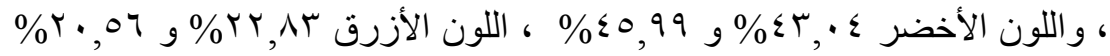
على التو الي.

1- أستاذ الهندسة الزراعية ـ كلية الزراعة - جامعة القاهرة - مصسر.

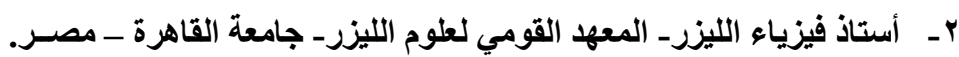

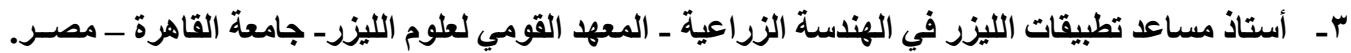

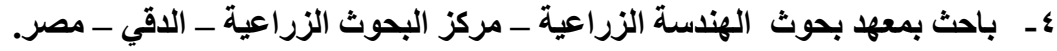

